Mergen, F., P. Hoekstra and R. M. Echols (1955): Genetic control of oleoresin yield and viscosity in slash pine. Forest Science 1: 19-30.

Pswarayi, I. Z., R. D. BARNeS, J. BiRKs and P. J. KANOwski (1996): Genetic parameter estimates for production and quality traits of Pinus elliottii Engelm. var. elliottii in Zimbabwe. Silvae Genetica 45: 216-222.

Qin, J., H. M. Liang, L. H. Zeng, M. Luo, B. X. He, Q. Y. PaN and X. Y. WANG (2005): Study on resin productivity in a 20-year-old Half-sib progeny test of Pinus massoniana. Guangdong Forestry Science and Technology 21: 30-34.

Roberds, J. H., B. L. Strom, F. P. Hain, D. P. Gwaze, S. E. McKeand and L. H. LotT (2003): Estimates of genetic parameters for oleoresin and growth traits in juvenile loblolly pine. Can J For Res 33: 2469-2476.

Rodrigues, K. C. S., P. C. N. Azevedo, L. E. Sobreiro, P. PELISSARI and A. G. FEtT-Neto (2008): Oleoresin yield of Pinus elliottii plantations in a subtropical climate: effect of tree diameter,wound shape and concentration of active adjuvants in resin stimulating paste. Ind Crops Prod 27: 322-327.

SquillaCe, A. E. (1965): Combining superior growth and timber quality with high gum yield in slash pine. Proc. 8th South For. Tree Improv. Conf. 73-76.

Squillace, A. E. and G. W. Bengston (1961): Inheritance of gum yield and other characteristics of slash pine. Proc. $6^{\text {th }}$ South For. Tree Improv. Conf. 85-96.

Tadesse, W., N. Nanos, F. J. Aunon, R. Alia and L. GiL (2001): Evaluation of high resin yielders of Pinus pinaster AIT. For. Genet. 8: 271-278.

VAN NoORDWIJK, A. J. and G. DE JONG (1986): Acquisition and allocation of resources: their influence on variation in life history tactics. Am. Nat. 128 : 137-142.
Weng, H. L., H. W. CHEN and A. A. DuAN (2010): Selection of plus-tree with high-rosin production for Pinus kesiya var. 1angbianensis, Journal of Northwest Forestry University 25: 71-74.

WenG, Y. H., K. J. Tosh, Y. S. Park and M. S. Fullarton (2007): Age-related trends in genetic parameters for Jack pine and their implications for early selection. Silvae Genetica 56: 242-252.

YANG, Z. W., R. H. ZHeng, Z. H. FU, Q. J. Wu and Q. S. LIANG (2003): Study on selection of excellent families for industrial wood of Pinus massoniana. Scientia Silvae Sinicae 39: 74-80.

YU, X. (2000): Crown structure, growth performance, nutritional characteristics, and their genetic parameter estimates in juvenile loblolly and slash pine. A dissertation presented to the graduate school of the university of Florida in partial fulfillment of the requirements for the degree of Doctor of philosophy. University of Florida.

Zeng, L. H., Y. S. Wang, Z. C. Ruan, B. X. He, T. H. Li, Z. Y. QI, H. M. LIAN, J. QIN and X. L. ZHONG (1998): Analysis of resin yielding ability and genetic steadiness of high resinous masson's pine. Forestry Science and Technology of Guangdong Province 14: 1-6.

ZHANG, J. Z., F. Q. SHEN, J. M. JIANG and Q. F. LUAN (2010): Heritability estimates for real resin capacity and growth traits in high-gum-yielding slash pine. Journal of Zhejiang Forestry College 27: 367-373.

ZHAO, H. Z. and X. B. SHI (1984): Preliminary study on correlation of oleoresin yield with external morphology of Pinus massoniana. Practical Forestry Technology 7: 9-10.

\title{
Provenance variation in height development of Albizia falcataria under three levels of spacing in East Java, Indonesia
}

\author{
By S. Kurinobu ${ }^{\left.1),{ }^{*}\right)}$, O. Chigira ${ }^{2)}$, K. Matsune ${ }^{3)}$, M. Miura $^{1)}$ and M. NaieM ${ }^{4)}$
}

(Received 17 $7^{\text {th }}$ May 2012)

\begin{abstract}
Nine provenances of Albizia falcataria were planted at three square spacing levels $(2,3$, and $4 \mathrm{~m})$ in a split-plot design at Jember in East Java, Indonesia and measured

1) Forest Tree Breeding Center, FFPRI, Juo, Hitachi, Ibaraki 3191301, Japan.

$\left.{ }^{2}\right)$ Kyushu Breeding Office, Forest Tree Breeding Center, FFPRI, Gooshi, Kumamoto 861-1102, Japan.

$\left.{ }^{3}\right)$ Tsukuba Res. Inst., Sumitomo Forestry Co. Ltd., Tsukuba, Ibaraki 300-2646, Japan.

4) Faculty of Forestry, Gadjah Mada University, Yogyakarta 55281, Indonesia.

*) Corresponding author: Susumu KuRINobu. Forest Tree Breeding Center, FFPRI, Juo, Hitachi, Ibaraki 319-1301, Japan. Tel: +81-294-39-7304, Fax: +81-294-39-7352. E-Mail: Kurinobu_ssm@nifty.com
\end{abstract}

annually for six years, which is three quarters of its rotation age. The effect of spacing on mean height development became progressively evident, due to the decline in growth at closer spacing caused by intensified competition, in six provenances, i.e., three provenances each from Java and East Indonesia, which were considered better adapted to the site because of their better growth and higher survival. On the contrary, the height growth curves of two provenances from New Guinea were almost identical, irrespective of spacing, indicating a lack of plasticity to the favorable environment at wider spacing. Dominant height was defined as the average of the five tallest trees per sub-plot (350 stems/ha), the growth curves at the three spacing levels were similar in the above-mentioned six provenances and were regarded as a single curve according to AIC-values. In contrast, dominant height growth curves of the New 
Guinea provenances were differentiated in the order of 2,3 , and $4 \mathrm{~m}$ spacing, approximately proportional to the intensity of choosing dominant trees per sub-plot. These results suggest that provenance variation exists for mean and dominant height and their response to different spacing. The cause of this variation was presumably attributable to the difference in competitive ability as well as the plasticity to the given environment. The use of dominant height for growth modeling of $A$. falcataria was found to be the most suitable for the adapted provenances.

Key words: Albizia falcataria, height growth curve, provenance spacing trial.

\section{Introduction}

Fast-growing plantations of Albizia falcataria, one of the most popular multi-purpose legumes trees that has been planted widely in Southeast Asia (DJoGo, 1994; JOHAN and ROY, 2000), have become a major source of timber supply for solid wood industries as a substitute for the tropical natural forests (COSSALter and PyESмITH, 2003). Demand for timber from the plantations is increasing because the wood has acceptable properties of wood for panel and plywood industries (TAN, 1983; ANino, 1994; NEмото, 2002). Therefore, identification of suitable provenances for solid wood production and the growth model development are urgently required.
The dominant height-age relationship has been used to derive site index curves with the assumption that this relationship is less affected by differences in stand density and by most thinnings. Although this assumption is widely accepted (PIENAAR and SHIVER, 1984), several authors have argued that dominant height is not independent of stand density (CURTIS and REUKEMA, 1970; MACFARLANE et al., 2000; FERNANDEZ et al., 2011). In the case of mean height, there is much evidence that this increases with increasing spacing (HARMS et al., 2000; MACFARLANE et al., 2000; SHARMA et al., 2002). These studies suggest that mean height-age relationship is affected by stand density, and this may also be true of the dominant height-age relationship, however, only few papers had examined these relationships in relation to genetic aspects (WEBER et al., 2011; WILL et al., 2010).

In this paper, provenance variation was investigated in the height-age relationship by analyzing data collected from annual measurements in a provenance spacing trial of $A$. falcataria until six years old, three-quarters of the rotation age. To examine the response to spacing for each provenance, growth curves of mean height and dominant height were derived by two alternative models; a separate model where the curves were derived separately for the three spacing levels and a pooled model where a single curve was derived by pooling measurements of all spacing levels. Then the provenance

Table 1. - Provenances of Albizia falcataria tested in a provenance spacing trial in East Java.

\begin{tabular}{lllcccl}
\hline No & Code & \multicolumn{1}{c}{ Location of seed source } & $\begin{array}{c}\text { Altitude } \\
(\mathrm{m})\end{array}$ & Latitude & Longitude & Type of seed source \\
\hline 1 & PWJ & Purworejo, Central Java, Indonesia & 525 & $7^{\circ} 11^{\prime} \mathrm{S}$ & $109^{\circ} 59^{\prime} \mathrm{E}$ & Plantation \\
2 & WNG & Wonogiri, Central Java, Indonesia & 140 & $7^{\circ} 32^{\prime} \mathrm{S}$ & $110^{\circ} 41^{\prime} \mathrm{E}$ & Plantation \\
3 & TGR & Trenggarek, East Java, Indonesia & 150 & $8^{\circ} 04^{\prime} \mathrm{S}$ & $111^{\circ} 42^{\prime} \mathrm{E}$ & Plantation \\
4 & NTT & Flores, East Indonesia & 280 & $8^{\circ} 30^{\prime} \mathrm{S}$ & $122^{\circ} 39^{\prime} \mathrm{E}$ & Natural population \\
5 & MLK & Halmahera, Maluku, East Indonesia & 150 & $0^{\circ} 36^{\prime} \mathrm{N}$ & $127^{\circ} 52^{\prime} \mathrm{E}$ & Natural population \\
6 & TT & Timor Timur, East Indonesia & n. a. & n. a. & n. a. & Natural population \\
7 & WMN & Hobikoshi, Wamena, Papua & 1,700 & $4^{\circ} 10^{\prime} \mathrm{S}$ & $139^{\circ} 10^{\prime} \mathrm{E}$ & Natural population \\
8 & PNG & Papua New Guinea & n. a. & n. a. & n. a. & Natural population \\
9 & SLM & Kakadeke, Solomon Island & 100 & $7^{\circ} 35^{\prime} \mathrm{S}$ & $158^{\circ} 28^{\prime} \mathrm{E}$ & Natural population \\
\hline
\end{tabular}

n. a.: Data were not available.

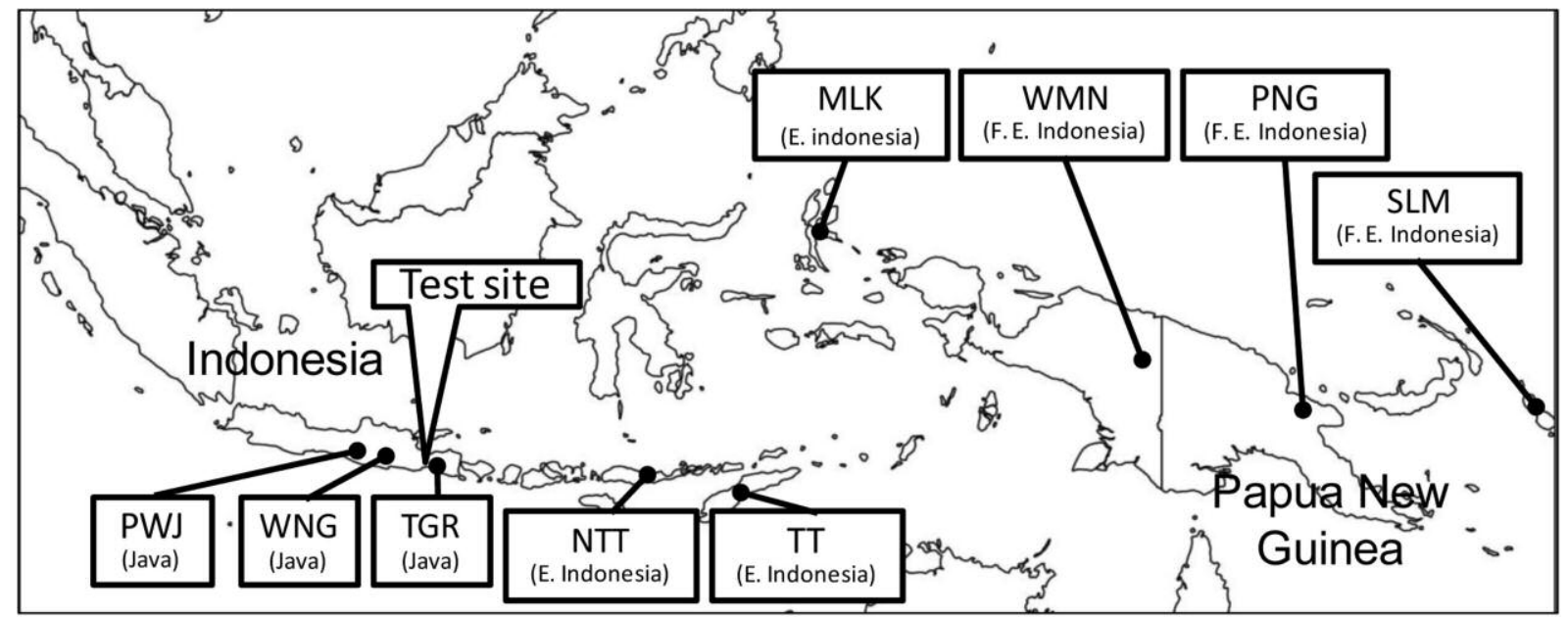

Figure 1. - Geographical location of the nine Albizia falcataria provenances tested in a spacing trial in East Java. 
variation in response to spacing and the validity of the dominant height concept were investigated based on the results of model selection.

\section{Materials and Method}

A provenance spacing trial was established in January 2005 at Jember in east Java, Indonesia $\left(8^{\circ} 11^{\prime} \mathrm{S}\right.$, $113^{\circ} 33^{\prime} \mathrm{E}, 60 \mathrm{~m}$ above sea level) to identify the best suited provenance in the region for growth as well as to examine optimum spacing for plantation establishment. Nine provenances were tested, i.e., PWJ, WNG and TGR were from Java; NTT, MLK and TT were from East Indonesia; WMN and PNG were from New Guinea; and SLM was from Solomon Island (Table 1 and Figure 1). Bulk seed collections were made from around 20 trees of above-average growth and form in each provenance, except for the Solomon Island where the seeds were collected from only a few mother trees. The three provenances in Java were from plantations, whilst the other collections were from natural stands.

The field layout of the trial was a split-plot design consisting of four replications each with three main plots of square spacing: $2,3,4 \mathrm{~m}$, in which the nine provenances were allocated randomly to the sub-plots. The sub-plot was a square of $12 \times 12 \mathrm{~m}$ in size $\left(=144 \mathrm{~m}^{2}\right)$ and the number of trees planted per sub-plot for $2 \mathrm{~m}$ spacing, the $3 \mathrm{~m}$ and the $4 \mathrm{~m}$ were $36(=2,500$ trees/ha), 16 $(=1,111$ trees/ha) and 9 (=625 trees/ha), respectively. There were no buffer rows between main plots and between subplots, but the trial was surrounded with operational plantations of $A$. falcataria on all four sides. Tree height and diameter at breast height (dbh) were measured at $8,14,26,33,38,48,60$ and 72 months after planting on all surviving trees. Tree height was measured with a Blume-Leiss hypsometer and diameter was measured with a diameter tape. Dominant trees were determined as the five tallest trees per sub-plot (350 trees/ha), which is approximately the same as the number in the local yield table: 330 to 465 trees/ha at age 6 (SUHARIAN et al., 1975).

Analysis of variance of height, $\mathrm{dbh}$ and survival rate of sub-plot means $\left(y_{i j k}\right)$ was conducted at each of the measurement time using the following linear model,

$$
y_{i j k}=\mu+S_{i}+R_{j}+E(S R)_{i j}+P_{k}+S P_{i k}+E(S P R)_{i j k}
$$

where $\mu, S_{i}, R_{j}, E(S R)_{i j}, P_{k}, S P_{i j}$ and $E(S P R)_{i j k}$ are the population mean, $i$-th spacing effect, $j$-th replication effect, major plot error of $i$-th spacing and $j$-th replication, $k$-th provenance effect, and the interaction between $i$-th spacing, $k$-th provenance and sub-plot error with $y_{i j k}$.

The Chapman-Richards function (PIENAAR and TURNBULL, 1973; RICHARDS, 1959) was used to fit data from the eight measurements of provenance spacing mean. This function is known as a flexible growth curve and is given in the following form,

$$
Y_{t}=A[1-\exp (-b t)]^{c}
$$

where $Y_{t}$, average height at age $t$ in months; $A$, upper asymptote $(\mathrm{m}) ; b$, a rate of growth parameter $b=1 / t$

Table 2. - Summary of analysis of variance of growth parameters for nine

\begin{tabular}{|c|c|c|c|c|c|c|c|c|c|}
\hline \multirow[t]{2}{*}{ Source of variation } & \multirow{2}{*}{$\begin{array}{l}\text { Degrees of } \\
\text { freedom }\end{array}$} & \multicolumn{8}{|c|}{$\begin{array}{l}\text { Age of measurement in months after } \\
\text { planting }\end{array}$} \\
\hline & & 8 & 14 & 26 & 33 & 38 & 48 & 60 & 72 \\
\hline \multicolumn{10}{|l|}{ a. Mean height } \\
\hline Spacing & 2 & ns & ns & ns & ns & ns & $* *$ & $* *$ & $* *$ \\
\hline Replication & 3 & ns & ns & ns & ns & $* *$ & ns & ns & * \\
\hline Spacing x Replication & 6 & $* *$ & $* *$ & $* *$ & $* *$ & $*$ & ns & ns & ns \\
\hline Provenance & 8 & $* *$ & $* *$ & $* *$ & $* *$ & $* *$ & $* *$ & $* *$ & $* *$ \\
\hline Spacing $x$ Provenance & 16 & ns & ns & ns & ns & ns & ns & $*$ & ns \\
\hline \multicolumn{10}{|l|}{ b. Dominant height } \\
\hline Spacing & 2 & $*$ & $* *$ & $*$ & $*$ & $*$ & ns & ns & $*$ \\
\hline Replication & 3 & ns & ns & ns & ns & $*$ & ns & ns & $*$ \\
\hline Spacing x Replication & 6 & $* *$ & $* *$ & $* *$ & $* *$ & $* *$ & $* *$ & $*$ & ns \\
\hline Provenance & 8 & $* *$ & $* *$ & $* *$ & $* *$ & $* *$ & $* *$ & $* *$ & $* *$ \\
\hline Spacing $\mathrm{x}$ Provenance & 16 & ns & ns & ns & ns & ns & ns & ns & ns \\
\hline \multicolumn{10}{|l|}{ c. Mean diameter } \\
\hline Spacing & 2 & ns & ns & $* *$ & $* *$ & $* *$ & $* *$ & $* *$ & $* *$ \\
\hline Replication & 3 & ns & ns & ns & ns & ns & ns & ns & ns \\
\hline Spacing x Replication & 6 & $* *$ & $* *$ & $*$ & ns & ns & ns & ns & ns \\
\hline Provenance & 8 & $* *$ & $* *$ & $* *$ & $* *$ & $* *$ & $* *$ & $* *$ & $* *$ \\
\hline Spacing $\mathrm{x}$ Provenance & 16 & ns & ns & ns & ns & ns & $*$ & $*$ & ns \\
\hline \multicolumn{10}{|c|}{ d. Survival rate (arcsine transformed) } \\
\hline Spacing & 2 & ns & $* *$ & ns & $*$ & $*$ & $*$ & $*$ & ns \\
\hline Replication & 3 & ns & $*$ & ns & ns & ns & ns & ns & ns \\
\hline Spacing $x$ Replication & 6 & $*$ & ns & ns & ns & ns & ns & ns & ns \\
\hline Provenance & 8 & ns & ns & $* *$ & $* *$ & $* *$ & $* *$ & $* *$ & $* *$ \\
\hline Spacing $\mathrm{x}$ Provenance & 16 & ns & ns & ns & ns & ns & ns & ns & ns \\
\hline
\end{tabular}
provenances of Albizia falcataria in a provenance spacing trial in East Java.

*: significant at $5 \%$ level, ${ }^{* *}$ : significant at $1 \%$ level, ns: not significant. 
(months ${ }^{-1}$ ); $c$, a shape of curve parameter (dimensionless). According to a previous study on Richards function, it was recommended that parameters $A$ and $b$ should be estimated for each set of data by fixing parameter $c$ at an optimum value at the trial to avoid overparameterization (DANJON and HERVE, 1994). Thus the trial means for the respective mean height and dominant height were fitted to the function to estimate parameter $c$, then parameters $A$ and $b$ were estimated for each provenance by fitting the function to each of the provenance spacing mean with the fixed parameter $c$.

In order to examine the effect of different spacing on height development, two models were derived for each of the provenances for mean height and dominant height; one with the height growth curves corresponding to the respective spacing (separate model) and the other with a single curve combining all measurements from the three different spacing levels (pooled model). The Akaike information criterion (AIC) was calculated for each of the models to compare the relative goodness of fit with the following formula,

$$
A I C=2 k-2 \ln (L)
$$

where $k$ is the number of parameters in the model, and $L$ is the maximized value of the likelihood function for the estimated model (AKAIKE, 1973). In this study, $k$ was 8 for the separate model and that of the pooled model was 4 .

\section{Results}

Provenance variation was significant $(p<0.01)$ for both mean and dominant height throughout the period of measurement, while the spacing effect was not consistently significant and rather contrasting between mean height and dominant height, i.e., spacing was significant in dominant height until 38 months old $(p<0.05)$, whereas in mean height it was significant from 48 months $(p<0.01)$ (Table $2 a, b)$. With regards to provenances, these could be categorized into two types; Java provenances (PWJ, WNG, TGR), East Indonesia provenances (NTT, MLK, TT) and the Solomon provenance (SLM) showed greater variation in mean height growth due to the declined growth under narrower spacing, whereas the New Guinea provenances (WMN and PNG) showed almost identical height growth curves irrespective of the spacing (Figure 2). In the dominant height development, the $2 \mathrm{~m}$ spacing resulted in greatest growth by 38 months in most of the provenances; but after 38 months the differences among treatments with wider spacing were progressively diminished in TGR, MLK, TT, whilst those in WMN and PNG were increased (Figure 3). The growth curves of the three spacing levels almost identical in the provenances of PWJ, WNG, TGR, NTT, MLK, TT and SLM, while those in WMN, PNG were differentiated in the higher order of $2 \mathrm{~m}, 3 \mathrm{~m}$ and $4 \mathrm{~m}$ spacing. The replication effect for both dominant and mean height was generally weak and non-significant $(p>0.05)$, except for the measurements at 38 and 72 months in both height analyses.

Estimates of the parameter c in Eq. (2) were 1.14 (standard error (SE) 0.18), fitted to the data of mean height, and 1.02 (SE 0.13) for dominant height. As these were not significantly different from each other $(p>0.05)$, in the subsequent analysis, the provenancespacing mean was fitted to Eq. (2) using a common para-

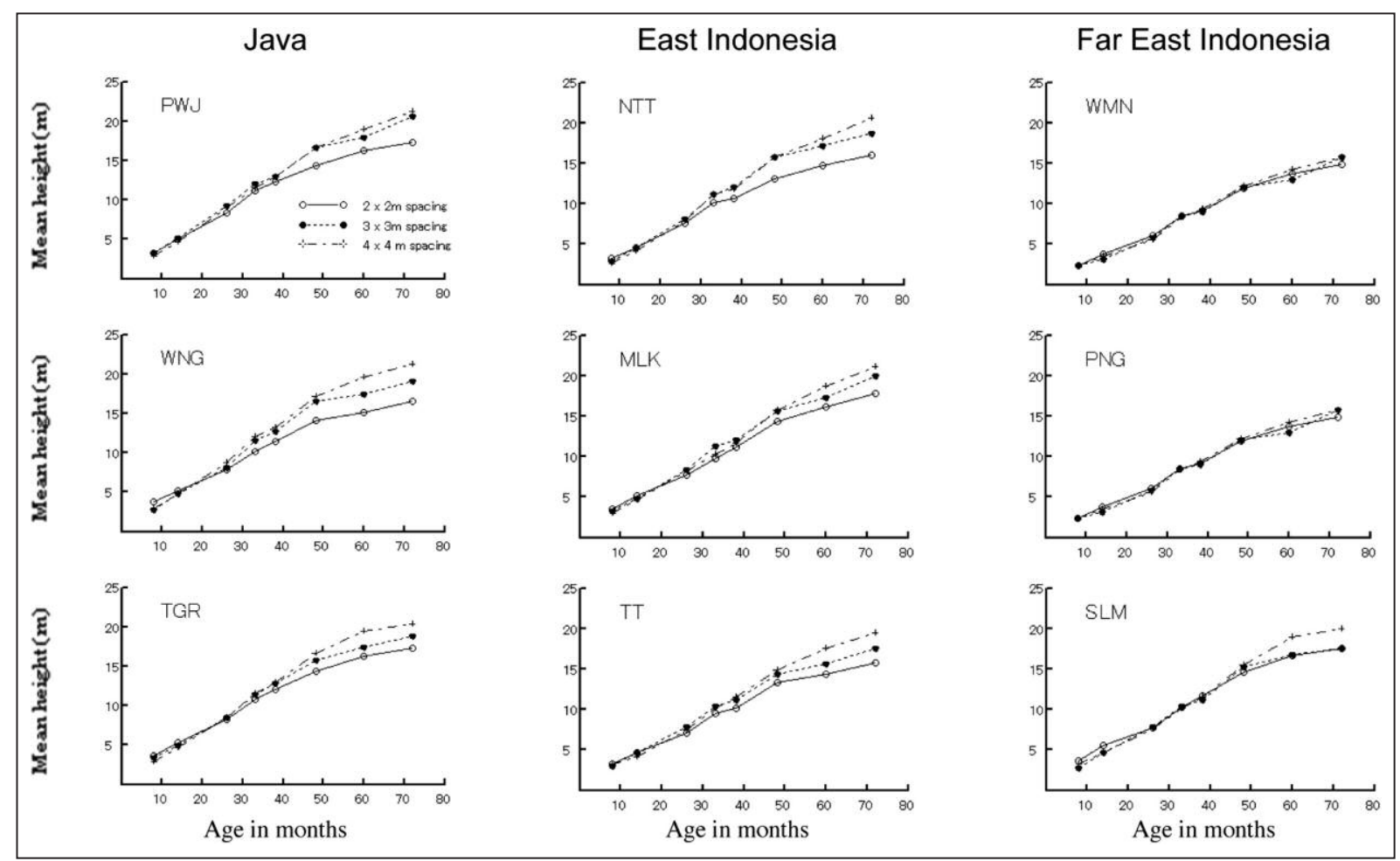

Figure 2. - Mean height growth for nine provenances of Albizia falcataria under three levels of spacing in a provenance spacing trial in East Java. 


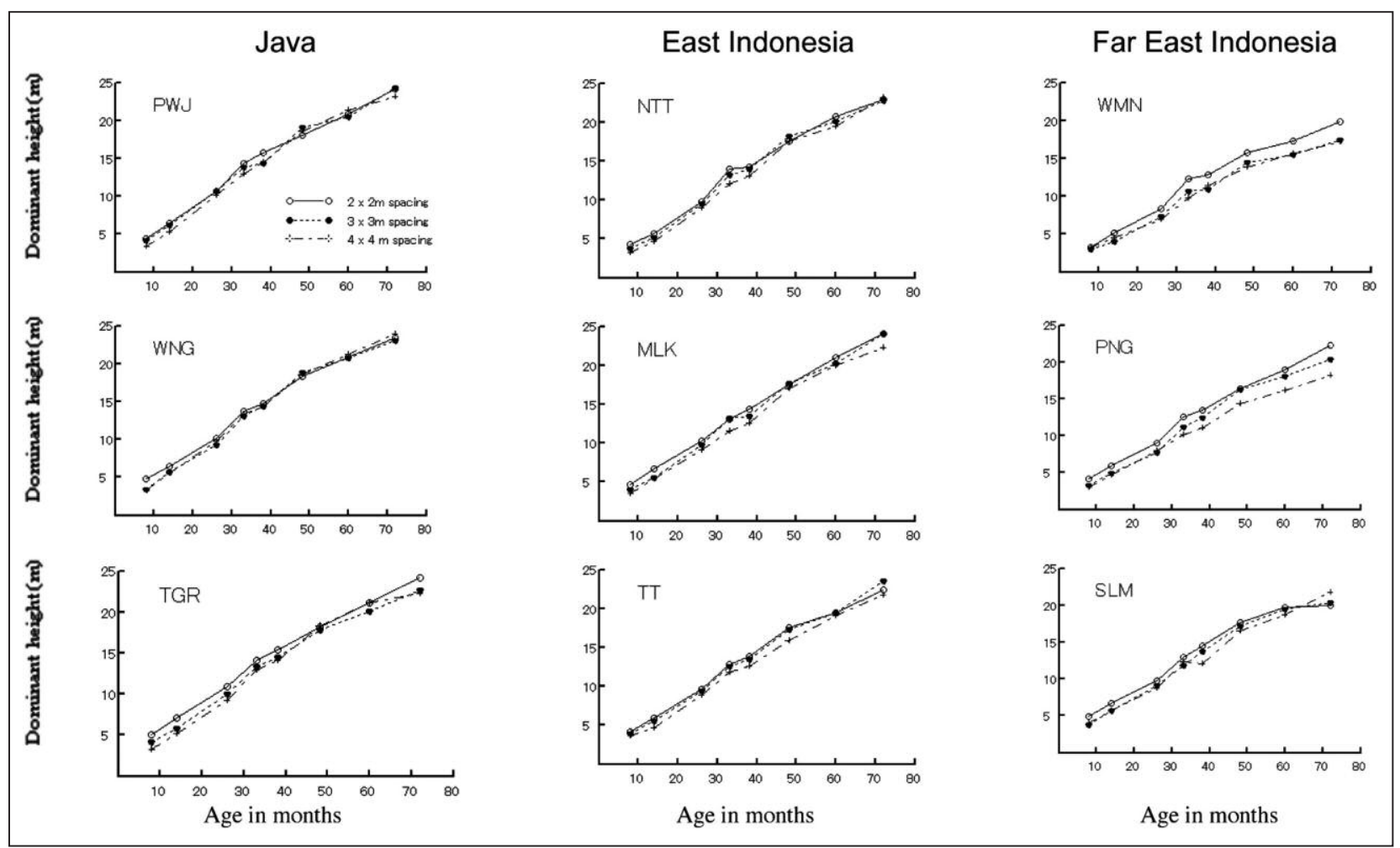

Figure 3. - Dominant height growth for nine provenances of Albizia falcataria under three levels of spacing in a provenance spacing trial in East Java.

Table 3. - Model evaluation for height development by Akaike's Information Criterion (AIC).

\begin{tabular}{|c|c|c|c|c|c|c|c|}
\hline \multirow{2}{*}{$\begin{array}{l}\text { Provenance } \\
\text { code }\end{array}$} & \multicolumn{3}{|c|}{$\begin{array}{l}\text { Parameters of height growth } \\
\text { curve (pooled) }\end{array}$} & \multicolumn{2}{|c|}{ Pooled model } & \multicolumn{2}{|c|}{ Separate model } \\
\hline & $\mathrm{A}$ & $\mathrm{b}$ & $\mathrm{R}^{2}$ & $\sigma_{\mathrm{e}}^{2}$ & AIC & $\sigma_{\mathrm{e}}{ }^{2}$ & $\mathrm{AIC}$ \\
\hline \multicolumn{8}{|l|}{ a. Mean height } \\
\hline PWJ & 30.5 & 0.016 & 0.973 & 0.838 & 49.3 & 0.143 & $\underline{38.9}$ \\
\hline WNG & 29.4 & 0.016 & 0.949 & 1.546 & 55.7 & 0.332 & $\underline{47.7}$ \\
\hline TGR & 28.9 & 0.016 & 0.973 & 0.795 & 48.8 & 0.251 & $\underline{44.7}$ \\
\hline NTT & 30.8 & 0.014 & 0.960 & 1.135 & 52.5 & 0.203 & $\underline{42.5}$ \\
\hline MLK & 36.4 & 0.012 & 0.978 & 0.659 & 46.8 & 0.191 & $\underline{41.9}$ \\
\hline TT & 28.8 & 0.014 & 0.967 & 0.813 & 49.0 & 0.197 & $\underline{42.2}$ \\
\hline WMA & 32.0 & 0.010 & 0.987 & 0.253 & $\underline{36.8}$ & 0.220 & 43.4 \\
\hline PNG & 26.8 & 0.014 & 0.984 & 0.338 & $\underline{39.9}$ & 0.247 & 44.6 \\
\hline SLM & 31.7 & 0.014 & 0.976 & 0.684 & $\underline{47.2}$ & 0.393 & 49.4 \\
\hline \multicolumn{8}{|c|}{ b. Dominant height } \\
\hline PWJ & 38.0 & 0.015 & 0.992 & 0.339 & $\underline{39.9}$ & 0.263 & 45.2 \\
\hline WNG & 39.8 & 0.013 & 0.992 & 0.361 & $\underline{40.5}$ & 0.297 & 46.5 \\
\hline TGR & 35.7 & 0.015 & 0.987 & 0.536 & $\underline{44.7}$ & 0.307 & 46.8 \\
\hline NTT & 41.2 & 0.012 & 0.989 & 0.452 & $\underline{42.9}$ & 0.299 & 46.6 \\
\hline MLK & 43.3 & 0.012 & 0.986 & 0.580 & $\underline{45.5}$ & 0.287 & 46.2 \\
\hline TT & 40.0 & 0.012 & 0.989 & 0.429 & $\underline{42.3}$ & 0.220 & 43.4 \\
\hline WMA & 28.3 & 0.015 & 0.967 & 0.884 & 49.9 & 0.306 & $\underline{46.8}$ \\
\hline PNG & 35.1 & 0.013 & 0.965 & 1.136 & 52.5 & 0.242 & $\underline{44.4}$ \\
\hline SLM & 30.4 & 0.017 & 0.979 & 0.696 & $\underline{47.4}$ & 0.465 & 51.2 \\
\hline
\end{tabular}

$\mathrm{A}$ and $\mathrm{b}$ are the parameters of equation (2) in the text, and $\mathrm{R}^{2}$ is the coefficient of determination. AIC was calculated with equation (3) in the text using residual mean square $\left(\sigma_{e}^{2}\right)$. Smaller AIC values are underlined as the values selected for the respective provenance. Pooled model and separate model are explained in the text. 


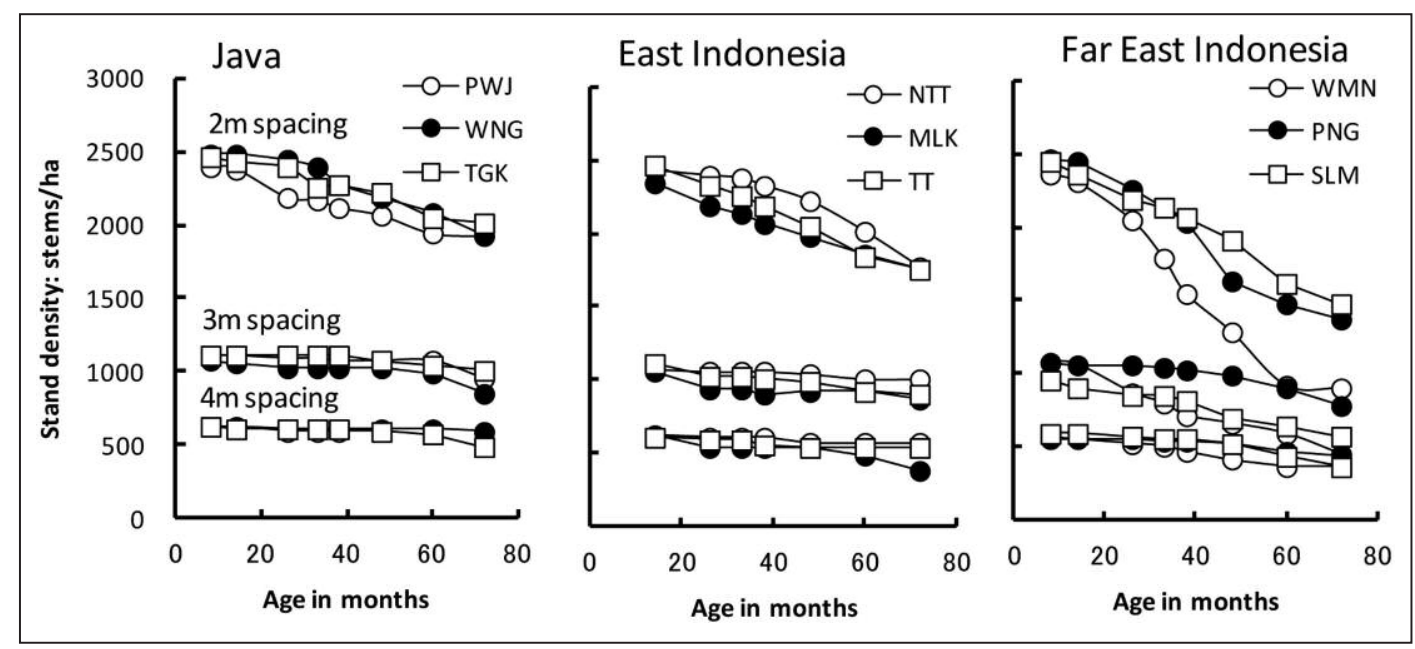

Figure 4. - Age trends in survival for nine provenances of Albizia falcataria under three levels of spacing at a trial in East Java.

meter $c, 1.08$, derived from the averages of mean height and dominant height.

The two models derived for each of the nine provenances using mean and dominant height respectively, and then compared using AIC (Table 3), agreed with the provenance results presented above, i.e., the separate model for mean height development and the pooled model for the dominant height, respectively, were preferred in Java provenances (PWJ, WNG, TGR) and East Indonesia provenances (NTT, MLK, TT), whereas those for New Guinea provenances (WMN, PNG) were com-

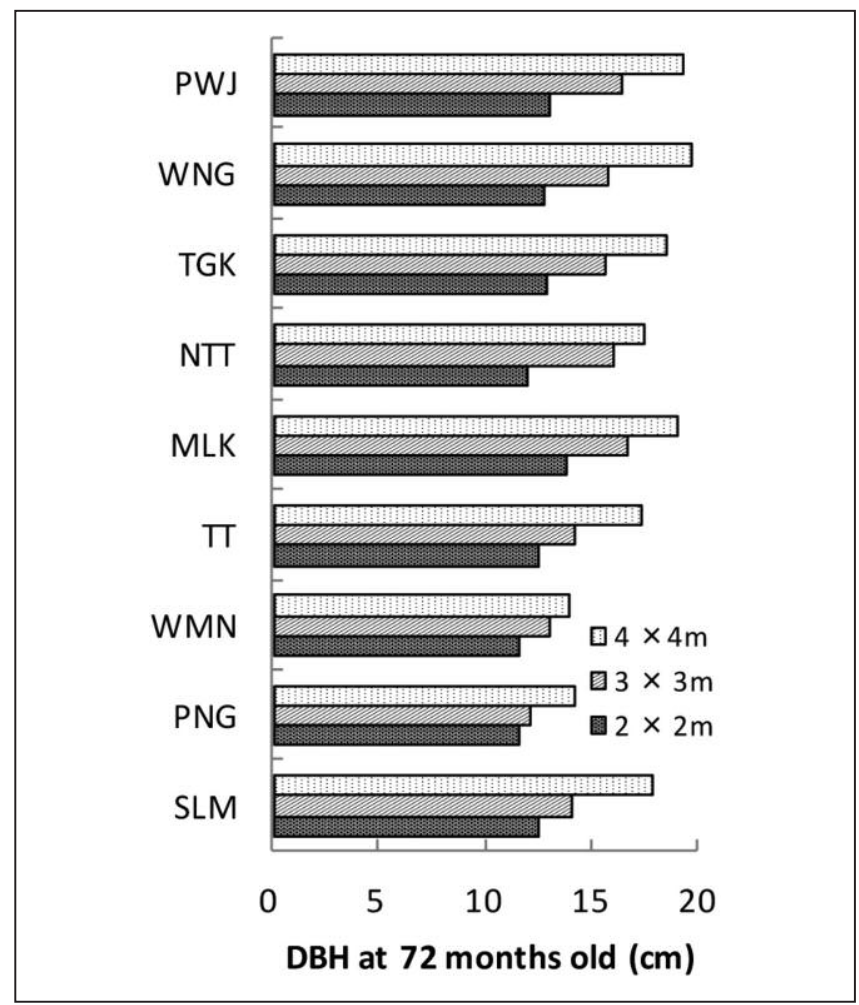

Figure 5. - Mean diameter at 72 months for nine provenances of Albizia falcataria under three levels of spacing in a provenance spacing trial in East Java. pletely opposite to the preceding six provenances. In the case of SLM, the pooled model was preferred both for mean height and dominant height.

Provenance variation in dbh was significant $(p<0.01)$ throughout the period, and survival rate was significant ( $p<0.01$ ) from 26 months to the end of the measurement period (Table 2). The spacing effect for both mean dbh and survival was significant from 26 to 33 months, i.e. at the onset of intensified competition. The declining trend in survival (Figure 4, significance not measured) differed with initial spacing as well as between provenances. By 72 months, the reduction in stand density was most evident in the $2 \mathrm{~m}$ spacing (i.e. average survival rate $=66 \%$ ), where the Far East Indonesian provenances (WMN, PNG, SLM) showed a rapid reduction, followed by the East Indonesian provenances (NTT, MLK, TT). The Java provenances (PWJ, WNG, TGK) had the lowest mortality at this spacing. This geographic trend was similar for survival and dbh in both the 3 and $4 \mathrm{~m}$ spacing (Figure 4 and 5), where the same regional order was observed despite minor provenance variation. In addition, the positive response of New Guinea provenances (WMN, PNG) to the wider spacing of $4 \mathrm{~m}$, was small, i.e., only $22 \%$ and $20 \%$, respectively, as compared to the average of other provenances (44\%).

\section{Discussion and Conclusions}

This provenance spacing trial revealed that there is provenance variation for both mean and dominant height growth in relation to spacing, as demonstrated by the contrasting pattern of height growth curves for the two height measurements (Figure 2 and 3). For the Java (PWJ, WNG, TGR ) and East Indonesian (NTT, MLK, TT) provenances, mean height was greater for the widest spacing ( $4 \mathrm{~m}$ or 625 stems/ha), whilst dominant height at the different spacing levels were almost identical after 48 months. The curves of the New Guinea provenances (WMN, PNG) showed no difference in mean height. A similar result to the former type of response was also reported for loblolly pine in a seed source spac- 
ing trial, where the spacing effect was significant in mean height but not significant in dominant height, although the relative rank of seed sources was consistent in both mean and dominant height (WILL et al., 2010). However, the latter type of response found here has not been reported elsewhere as yet. These latter differences were presumably attributable, not only to the difference in competitive ability at different spacing levels (ADAMs et al., 2008), but also to the plasticity to the given environment that would be deduced from the growth response in wider spacing.

In the mean height development of better adapted provenances in Java and East Indonesia which showed better growth and survival, the variation in height growth among spacing treatments is regarded as a consequence of higher survival at narrower spacing, coupled with their ability to adapt the given environment. Higher survival at narrower spacing would bring about a decline in mean height growth due to the increase in the number of suppressed trees caused by the intensified competition, as in the case of loblolly pine (WILL et al., 2010), while in the wider spacing the trees can continue their growth by adapting to the favorable environment and capturing the site. In contrast, with the poorly adapted provenances of WMN and PNG, the trees in wider spacing could not respond well to their spacing advantages, thus the mean height development was similar, irrespective of the spacing.

In the case of dominant height, the pattern of height development may also have been affected by the intensity of choosing five dominant trees per sub-plot; the initial selection intensity in the $2 \mathrm{~m}, 3 \mathrm{~m}$ and $4 \mathrm{~m}$ spacings was 1.54, 1.08 and 0.64, respectively (FALCONER, 1986). This difference was clearly reflected in the height response of the less adapted provenances (WMN and PNG), and became more obvious at older ages, probably due to a lack of plasticity of the trees growing at the wider spacing. In the well-adapted provenances, a similar trend was observed up until approximately 38 months, but thereafter the difference gradually diminished due to the stable growth of trees adapted to the wider spacing and the declining growth caused by competition in narrow spacing.

The altitude of WMN was $1,700 \mathrm{~m}$, which is much higher than those of other provenances (Table 1). Therefore, the difference between the provenance location and test environment might be a major cause for its peculiar response to spacing. Though location information of PNG was not available, it would probably be similar to WMN, based on its poor growth and lower survival. It is recognized that populations from plantations often outperform natural stands due to prior-selection, thinning and/or the alleviation of inbreeding depression as a result of the mixed planting (LAURIDSEN and KJAER, 2002). This would account for the better performance of Java provenances (PWJ, WNG, TGR), because they are regarded as land races that has adapted to the local environment through several decades of domestication. The East Indonesia provenances (NTT, MLK, TT) and SLM, although they were from natural stands, were growing at lower elevations similar to the trial site; altitudes for NTT, MLK and SLM were all below $300 \mathrm{~m}$
(Table 1) and that of the trial was $60 \mathrm{~m}$. Therefore the response to the spacing of WMN and probably PNG, which was characterized by poor plasticity of growth in wider spacing and higher mortality in narrow spacing, might be primarily attributable to the large differences in growing conditions between their habitat and the trial site.

The practical implication in this study is that the use of the dominant height concept is feasible for deriving height growth curves for the adapted provenances of A. falcataria from Java and East Indonesia, because the dominant height development was less affected by spacing levels (Figures 2 and 3). This was verified by the result of the alternative model selection with AIC (Table 4). Nevertheless it should be noted that this rule is not valid for the less adapted provenances, because the pattern of the curves was quite the opposite. In forestry generally, less adaptable provenances are rarely used for large scale reforestation, despite there always being a risk of "off-site" planting (ZoBEL et al., 1987).

Dominant height might be a better indicator of stand productivity than mean height, because it is less affected by spacing, i.e. stand density, after crown closure. The well adapted provenances, such as those from Java, tended to show better height growth and greater survival. A similar trend was also reported in loblolly pine for family means (ADAMs et al., 2008). This positive relationship between growth and survival brings about an earlier start of competition, thus affecting mean height development of the adapted provenances and consequently underestimating their potential productivities when thinning were practiced. Therefore the use of dominant height is recommended to reduce such bias caused by the positive relationship between growth and survival.

In conclusion, provenance variation exists for mean and dominant height and their response to different spacing levels. The well adapted provenances perform well at wider spacing, hence the mean height tended to be higher in wider spacing despite their dominant height being similar regardless of spacing. On the other hand those less adapted provenances showed the opposite trend. This was verified by the result of alternative model selection for height growth curves; the separate model for mean height and the pooled model for dominant height were preferred for the well adapted provenances, and vice versa for the less adapted provenances. The cause of this variation is presumably attributable to the difference in competitive ability as well as the plasticity of the provenance to the given environment. Therefore the use of dominant height for growth modeling of A. falcataria was found to be the most suitable for the well adapted provenances.

\section{Acknowledgements}

The authors greatly appreciate Mr. BANGBANG, and the staff at Kutai Timber Indonesia for their support in conducting periodic measurements of provenance spacing trial of A. falcataria at Jember, Indonesia. We are also grateful to Dr. Y. IDE at the University of Tokyo and Mr. K. NAKAmuRA at Sumitomo Forestry Co. Ltd. for their 
support in promoting this research project. We are also indebted to Dr. B. LeKsono and Dr. A. Nirsatmanto at Forest Biotechnology and Tree Improvement Center in Indonesia for their support in collecting location information of the provenances and the anonymous reviewers for their constructive comments on an earlier version of this manuscript.

\section{References}

Adams, J. P., S. B. LAND, K. L. Belli and T. G. Matney (2008): Comparison of 17-year realized plot volume gains with selection for early traits for loblolly pine (Pinus taeda L.). For. Ecol. Manag. 255: 1781-1788.

AKAIKE, H. (1973): Information theory and an extension of the maximum likelihood principle. $2^{\text {nd }}$ International Symposium on Information Theory, Petrov, B. N., and CsaKI, F. (eds.), Akadamiai Kiado, Budapest: 267-281.

ANINO, E. (1994): Commercial plantation establishment, management, and wood utilization of Paraserianthes falcataria by PICOP Resources, Inc. Proceedings of a workshop on Albizia and Paraserianthes species, Bislig, Surigao del Sur, Philippines, Nov. 13-19, 1994, Winrock International, 1997: 131-139.

Cossalter, C. and C. Pye-Smith (2003): Fast wood forestry. Myths and Realities, Forest Perspectives. Center for International Forestry Research, Bogor Indonesia, 50pp.

CurTis, R. O. and D. L. Reukema (1970): Crown development and site estimates in a Dougras-fir plantation spacing test. For. Sci. 16(3): 287-301.

DANJON, F. and J. C. HeRve (1994): Choice of a model for height-growth curves in maritime pine. Ann. Sci. For. 5 I: $589-598$.

DJogo, A. P. Y. (1994): Use of Albizia and Paraserianthes species in small-scale farming systems in Indonesia. Proceedings of a workshop on Albizia and Paraserianthes species, Bislig, Surigao del Sur, Philippines, Nov. 13-19, 1994, Winrock International, 1997: 27-36.

FALCONER, D. S. (1986): Introduction to quantitative genetics, second edition, 340pp. John Wiley \& Sons, New York.

Fernandez, C. A., H. E. Burkhart M. Strub and R. L. AMATEIS (2011): Effects of initial spacing on height development of loblolly pine. For. Sci. 57(3): 201-211.

HaRms, W. R., C. D. Whitesell and D. S. DeBell (2000): Growth and development of loblolly pine in a spacing trial planted in Hawaii. For. Ecol. Manag. 126(1): 13-24.
JoHAN, I. and E. Roy (2000): The contribution of Paraserianthes falcataria to sustainable swidden management practices among the Baduy of West Java. Human Ecology vol. 28: 1-17.

LAURIDSEN E. B. and E. D. KJAeR (2002): Provenance research in Gmelina arborea Linn., Roxb. A summary of results from three decades of research and a discussion of how to use them. Int. Forestry Rev. 4(1): 1-15.

MacFarlane, D.W., E. J. Green and H. E. Burkhart (2000): Population density influences assessment and application of site index. Can. J. For. Res. 30(9): $1472-1475$.

Nemoto, A. (2002): Farm tree planting and the wood industry in Indonesia: a study of Falcataria plantations and the Falcataria product market in Java. Policy Trend Report 2002: 42-51.

PienaAR, L.V. and K. J. TuRnBull (1973): The ChapmanRichards generalization of von Bertalanffy's growth model for basal area growth and yield in even-aged stands. For. Sci. 19: 2-22.

PiEnAAR, L.V. and B. D. SHIVER (1984): The effect of planting density on dominant height in unthinned slash pine plantations. For. Sci. 30(4): 1059-1066.

RICHARDS, F. J. (1959): A flexible growth function for empirical use. J. Exp. Bot. 10(29): 290-300.

Sharma, M., H. E. BuRkharT and R. L. Amateis (2002): Modeling the effect of density on the growth of loblolly pine trees. South. J. Appl. For. 26(3): 124-133.

SuHARIAN, A., K. SumernA and Y. Sudiono (1975): Yield table of ten industrial wood species. Lembaga Penelitian Hutan.

TAN, K. C. (1983): Growth data from Saba Softwoods Sdn Bhd plantations of some fast growing leguminous trees. Proc. Workshop on Leucaena Research in Asian Pacific Region. Singapore. 23-26 Nov 1982, IDRC. Ottawa, Canada: $155-156$.

Weber, J. C., C. Sotelo Montes, J. Cornelius and J. UGARTE (2011): Genetic variation in tree growth, stem form and mortality of Guazuma crinita in slowerand faster-growing plantations in the Peruvian Amazon. Silvae Genetica 60: 70-78.

Will, R., T. Hennessey, T. Lynch, R. Holeman and R. Heinemann (2010): Effects of planting density and seed source on loblolly pine stands in Southeastern Oklahoma. For. Sci. 56(5): 437-443.

Zobel, B. J., G. VAN WYK and P. STAHL (1987): Growing exotic forests. John Wiley \& Sons, New York, 508pp. 